\title{
Article
}

\section{'Kamikaze' heritage tourism in Japan: A pathway to peace and understanding?}

Sharpley, Richard Anthony john

Available at http://clok.uclan.ac.uk/33149/

Sharpley, Richard Anthony john ORCID: 0000-0002-2135-3206 (2020)

'Kamikaze' heritage tourism in Japan: A pathway to peace and understanding?

Journal of Heritage Tourism, 15 (6). pp. 709-726. ISSN 1743-873X

It is advisable to refer to the publisher's version if you intend to cite from the work. http://dx.doi.org/10.1080/1743873X.2020.1758117

For more information about UCLan's research in this area go to

http://www.uclan.ac.uk/researchgroups/ and search for < name of research Group>.

For information about Research generally at UCLan please go to

http://www.uclan.ac.uk/research/

All outputs in CLoK are protected by Intellectual Property Rights law, including Copyright law. Copyright, IPR and Moral Rights for the works on this site are retained by the individual authors and/or other copyright owners. Terms and conditions for use of this material are defined in the policies page.

\section{CLoK}

Central Lancashire online Knowledge www.clok.uclan.ac.uk

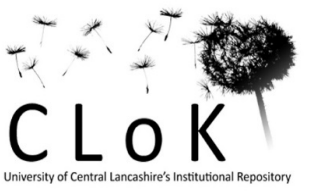


'Kamikaze' heritage tourism in Japan: A pathway to peace and understanding?

\author{
Richard Sharpley \\ Lancashire School of Business \& Enterprise, University of Central Lancashire, Preston \\ PR1 2HE UK rajsharpley@uclan.ac.uk
}

\begin{abstract}
Reflecting the wider belief that international tourism offers the opportunity to encourage peace and understanding amongst peoples and nations, one objective of Japan's recent tourism development policy is the enhancement of mutual understanding and the promotion of international peace. The purpose of this paper is to consider the extent to which this objective is achievable, particularly in the context of continuing controversy surrounding the country's confrontation of its twentieth century military heritage in general and its role in the Pacific War in particular. Based on research at two 'difficult' heritage sites, Chiran Peace Museum in Kagoshima Prefecture and Yūshūkan War Museum in Tokyo, it explores specifically how the kamikaze phenomenon is commemorated and interpreted for international visitors, in so doing revealing a significant degree of dissonance at both sites. Not only is a selective narrative of heroic sacrifice presented within a wider revisionist history of the Pacific War but also no attempt is made to acknowledge the prevailing cultural context that might underpin a more nuanced understanding of the kamikaze. Hence, the paper concludes that a meaningful opportunity to enhance international understanding has been missed.
\end{abstract}

Keywords: Tourism and peace; Japan; kamikaze; difficult heritage; dissonance; Chiran Peace Museum; Yūshūkan War Museum

\title{
Introduction
}

Over the last two decades, Japan has witnessed remarkable growth in inbound tourism. In 2000, 4.7 million international arrivals were recorded; by 2010, this figure had almost doubled to 8.6 million but, most notably, an average annual growth rate of around 28 percent was achieved between 2012 and 2017 (JNTO, 2019a). By 2018, international arrivals totalled almost 31.2 million (JNTO, 2019b). This rapid and sustained increase in international tourism reflects a deliberate policy on the part of the Japanese government, the principal objective of which is economic growth and regional revitalization (MLIT, 2016: 3), not least to address the challenge of an ageing and declining rural population (Crowe-Delaney, 2019). At the 
same time, however, it is also evidence of what Funck and Cooper (2015: 46) refer to as Japan's 'long-cherished role of fostering long-standing friendship and trust among nations', more recently formalized in its 2013 National Security Strategy (Oros, 2015). Indeed, an explicit objective of promoting tourism is the 'Enhancement of mutual understanding... To raise the current position of Japan our forerunners achieved in the condition of international peace [sic] and to accomplish our responsibilities at present and in the future' (MLIT, 2012: 4). A more recent policy accords greater significance to economic priorities yet still views tourism as a means to 'foster dynamic multicultural exchange' (MLIT, 2016: 3) including, more pragmatically, improving visitor access to and the presentation of heritage sites (MLIT, 2016: 9).

Yet, the extent to which such 'mutual understanding' can be achieved is debatable. On the one hand, 'Japan today projects an external image in which harmonious coherence provides a basis for technical efficiency and cultural excellence' (Pye, 2003: 45) whilst the contemporary hosting of major international events, such as the successful Rugby World Cup in 2019 and the Summer Olympics in Tokyo (postponed to 2021), points to positive symbiotic engagement with the international community. On the other hand, peaceful international (and indeed, domestic) relations are considered by some to remain challenged, not least by the manner in which Japan confronts its twentieth century military past. This is not to say that the country does not seek to promote peace through its wartime heritage. Notably, since it was designated by the government as 'Japan's International City of Peace' in 1949 (Yoshida, Bui \& Lee, 2016), Hiroshima has not only taken on the leadership of a global anti-nuclear weapon movement but has also developed a successful 'peace tourism' industry based upon its tragic past (Schäfer, 2016) and is emblematic of a contemporary Japan adopting a proactive role in international peace and prosperity (Oros, 2015). However, as some argue, Hiroshima primarily encourages a victim consciousness (for example, Siegenthaler, 2002) whilst, as the author of this paper has personally observed, the newly refurbished Hiroshima Peace Memorial Museum reveals powerfully the destructive effects of the A-bomb but little attempt is made to explain why it was dropped on the city. Hence, commentators such as Takenaka (2015: 16) argue that despite increasing manifestations of official remorse for the country's war-time activities, Japanese society today feels 'no obligation to engage in the post-war responsibility discourse', whilst others suggest that, as at Hiroshima, a dominant domestic narrative of victimhood shapes contemporary attitudes towards the county's military past and its approach to international relations (Orr, 2001; Yasuaki, 2002). Either way, however, it is evident from the literature that the representation 
of Japan's wartime heritage is both varied and controversial (Allen \& Sakamoto, 2013); as Nelson (2003: 445) summarizes, 'since the end of World War II, diverse interpretations over how to represent, acknowledge and atone for Japan's aggressive exploits throughout Asia and the Pacific have occasioned as much controversy and conflict as they have closure'.

Much of this controversy relates to Yasukini Jinja (Shinto shrine) in Tokyo where more than 2.5 million Japanese war dead, including a number of A-Class war criminals, are not only commemorated but apotheosised (Breen, 2004). Consequently, the shrine remains a source of both national and international political conflict. Yasukuni is referred to again later in this paper but a more specific and equally controversial issue is the commemoration of socalled kamikaze pilots, more formally referred to as tokkō, or Special Attack Force (Sheftall, 2008: 155), who undertook suicide missions during the last year of the Pacific War. (It should be noted that, as discussed later, suicide missions were also undertaken by divers, suicide boats and 'human torpedoes' or kaiten. However, the focus of this paper is on kamikaze aircraft pilots). Between October 1944, when the first officially sanctioned kamikaze operation took place against the Anercican fleet approaching the Philippines (Axell \& Kase, 2002: 40), and the formal end of the war on War on $2^{\text {nd }}$ Setember 1945, some 3,000 Japanese airmen died in kamikaze attacks (though some put the figure as high as 5,800 - see Sheftall, 2008). They are now commemorated at a number of museums and shrines around Japan and, unsurprisingly, a number of studies explore the kamikaze phenomenon and its contemporary representation (Allen \& Sakamoto, 2013; Axell \& Kase, 2002; Inuzuka, 2016; Nelson, 2003; Sakamoto, 2015; Sheftall, 2008; Yoshida, 2004). Typically, however, these focus on the kamikaze within competing discourses on war heritage within Japan; in contrast, the potential role of kamikaze heritage sites in both enhancing what is arguably limited knowledge of the phenomenon and encouraging wider international understanding and reconciliation through tourism has not been considered. This is a notable omission, not least given that, in addition to the broader objective of promoting mutual understanding, the most recent tourism policy in Japan targets Western nations, in particular the United States, as key international tourist markets (MLIT, 2016).

This paper, therefore, seeks to addreess this gap in the literature. Specifically, it explores the manner in which two heritage sites in Japan, namely, the Chiran Peace Museum in Kagoshima Prefecture (the country's principal heritage site dedicated to kamikaze pilots) and the Yūshūkan War Museum located within the grounds of Yasukuni Jinja in Tokyo, commemorate and interpret the exploits of the kamikaze pilots for both domestic and, in particular, international tourists. To do so, it is necessary to consider the historical context in 
which the kamikaze attacks were conceived, authorized and undertaken, but the first task is to review how tourism may in principal play a role achieving peace, understanding and reconciliation, particularly in the context of post-conflict heritage sites, as a framework for the subsequent discussion.

\section{Tourism, peace and mutual understanding}

It is observed that, pragmatically, 'tourism is far more dependent on peace than peace is on tourism' (Hall, Timothy \& Duval, 2004: 3); indeed, research has concluded that although international tourism may in some circumstances foster cross-cultural understanding, typically 'tourism is the beneficiary of peace rather than grounds for peace' Pratt \& Liu, 2016: 82). Nevertheless, it has long been suggested that tourism can be a pathway to international peace and mutual understanding. Following the First World War, travel was promoted to encourage peaceful relations between former adversarial nations whilst in 1967 , the United Nation's International Tourism Year was themed 'Tourism: Passport to Peace' (Wohlmuther \& Wintersteiner, 2014: 17). Subsequently, the World Tourism Organization (WTO, 1980) identified international tourism as a vital force for peace, an objective carried forward by D'Amore (1988) who, in 1986, founded the International Institute for Peace through Tourism. Since then, increasing attention has been paid to the relationship between tourism and peace (Blanchard \& Higgins-Desboilles, 2013; Moufakkir \& Kelly, 2010), the belief being that social and cultural connections through tourism 'spur dialogue and exchange, break down cultural barriers and promote the values of tolerance, mutual understanding and respect' (Rifai, 2013: 11).

Inevitably, such an overarching ambition for a phenomenon as extensive and diverse as contemporary tourism may be considered unrealistic (Litvin, 1998). Certain, particularly mass, forms of tourism are unlikely to offer opportunities to encourage peace and understanding (Harrison \& Sharpley, 2017); moreover, the increasing evidence of so-called 'overtourism' (Milano, Cheer \& Novelli, 2019; Pechlaner, Innerhofer \& Erschbamer, 2020) suggests that, increasingly, conflict and resentment between tourists and destination communities may actually be the outcome of tourism development. At the same time, as Farmaki (2017) observes, research into the tourism and peace nexus tends to be based upon the contact hypothesis - that is, it is assumed that contact between tourists and relevant members of destination societies provides the basis for developing mutual understanding and promoting peaceful relations. This, she argues, is simplistic; in order to assess the potential for reconciliation and peace through tourism it is necessary to take into account a variety of 
factors including the initial cause of the conflict and contemporary contextual influences that may inhibit its resolution, as well as the nature, role and governance of tourism in the destination. In the context of this paper, such contextual influences might include competing perspectives on how to commemorate Japan's war dead (Jeans, 2005; Yoshida, 2004), a longstanding sense of victimhood dating back to the politics of the immediate postwar years (Tsutsui, 2009) and contemporary shifts in what Oros (205) refers to as the country's security identity.

Nevertheless, it is acknowledged that in some contexts, particularly at tourist sites related to difficult pasts - or sites of difficult heritage (Logan \& Reeves, 2008) - the opportunity exists, through appropriate commemoration and interpretation, to encourage reconciliation and understanding (Batten, 2008). More specifically, heritage sites of or related to conflict between peoples and nations, such as battlefield sites, museums dedicated to violent pasts, sites of genocide or memorials to those have lost their lives in acts of terror or violence, represent a legitimized space where, in principal at least, visitors with direct, indirect or even no connection with the event, its victims and indeed its perpetrators may congress to both remember those who suffered in a violent past and also to reconcile differences in order to establish a more peaceful present and future (Gurler \& Ozer, 2013), to ensure that 'never again' can such events occur (Lollis, 2014; Williams, 2007). In short, postconflict heritage sites may foster accountability, justice, debate and reconciliation, or the transformation of 'relations of hostility and resentment to friendly and harmonious ones' (Bar-Siman-Tov, 2004: 4; Friedrich, Stone \& Rukesha, 2018), as a necessary foundation for peace-building (Buckley-Zistel \& Schaefer, 2014).

The extent to which this might occur inevitably depends on a number of factors, including those proposed by Farmaki (2017) referred to above. On the one hand, the opportunity exists at such sites to inform, educate and to present 'the truth', in so doing encouraging all stakeholders to reflect, communicate and overcome past differences in a spirit of tolerance and forgiveness. However, a number of requirements should necessarily be fulfilled, not least that the site be accessible and welcoming to all who wish to visit, and also be managed and presented in a manner that fosters reconciliation, including the appropriate or accurate representation of all stakeholders' heritages or stories (Kelly \& Nkabahona, 2010; Poria, 2007). Moreover, there should ideally exist both acknowledgement of the need for and a wider culture of reconciliation; in other words, all stakeholders should from the outset be committed to achieving such peace and understanding (Friedrich, Stone \& Rukesha, 2018). 
On the other hand, the very nature of difficult heritage challenges its effective or appropriate representation and commemoration. First and foremost, it is highly susceptible to political influence (Sharpley, 2009). In other words, the development and interpretation of difficult heritage may be undertaken to convey particular political messages or an authorized heritage discourse (Smith, 2006), reflecting what Light (2007: 747) refers to more generally as the 'cultural politics of tourism development'. It has long been recognized that, owing to its significance and visibility as a social and economic phenomenon, tourism generally may be exploited for political or ideological purposes (Richter, 1983), most usually to affirm or strengthen cultural identity. As Cano and Mysyk, 2004: 880) observe, 'the state may assume the role of marketer of cultural meanings, in which it attempts to make a statement about national identity by promoting [through tourism] selected aspects of a country's cultural patrimony' (see also Wight, 2016). Such a statement may be intended primarily for a domestic audience (Palmer, 1999); equally, it may also be intended for international tourist consumption, such as at the Kigali Genocide Memorial in Rwanda where the interpretation of the 1994 Genocide and its aftermath arguably seeks to legitimize the contemporary government of the country to international visitors (Sharpley \& Friedrich, 2016).

The outcome of political intervention in difficult heritage is but one potential source of dissonance or dissonant heritage. As Tunbridge and Ashworth (1996: 21) observe, '....all heritage is someone's heritage and therefore logically not someone else's, and the original meaning of an inheritance implies the existence of disinheritance'. This disinheritance occurs when there exists a 'lack of congruence at a particular time or place between people and the heritage with which they identify' (Ashworth \& Hartmann, 2005: 253) or, alternatively stated, dissonant heritage is manifested when the past is represented or interpreted in such a way that, for particular people or 'subaltern' (Smith, 2006: 35) groups, their past is distorted or displaced. All heritage is inevitably susceptible to dissonance, not only because of the existence of multiple interest groups but also because, over time, people's relationship with and understanding of past events may change. However, that dissonance may be enhanced when the representation of past events '(re)interpret[s] past events to meet contemporary political agendas, to erase or deny a particular past [or] to celebrate victory' (Sharpley, 2009, 150-1). Moreover, Ashworth and Hartmann (2005: 254) argue that not only does 'human tragedy imbue [dissonance] with a capacity to amplify the effects and thus render more serious what otherwise would be dismissable as marginal or trivial', but also that dissonance is inevitable in difficult heritage construction and interpretation. 
In the context of this paper, the existence of dissonance at difficult heritage sites in general and at post-conflict sites in particular is, by definition, likely to hinder the promotion of understanding and reconciliation. Specifically, unless the heritage of all those involved or with an interest in a former conflict is recognized and fully addressed at post-conflict sites, then the necessary foundations for peace-building referred to by Buckley-Zistel and Schaefer (2014) will not be in place. And as argued below, this is indeed the case at the two kamikaze heritage sites in Japan. Not only do they present an authorized revisionist narrative of heroic sacrifice of the kamikaze pilots' exploits, but little or no attempt is made to locate that narrative within the wider political and cultural context of the time, a context that might foster a more nuanced understanding of the kamikaze phenomenon amongst both domestic and international visitors. Therefore, before discussing the interpretation and commemoration of the kamikaze at Chiran Peace Museum and Yūshūkan War Museum, the following section offers an overview of the historical and cultural circumstances surrounding the kamikaze phenomenon.

\section{The kamikaze: The historical context}

The word 'kamikaze' is arguably imbued with a certain historical romanticism. Translating as 'divine wind', it was the name given to a powerful typhoon that, in 1281, destroyed the invading fleet of the Mongolian Emperor Kublai Khan as it approached Japan, leading the Japanese to believe that, if once again facing attack, their country would be similarly saved by a divine wind (Chiran, 2017: 11). However, contemporary perceptions of the kamikaze phenomenon vary both within and beyond Japan. It is suggested, for example, that to younger Japanese it 'is a curiosity from the past; to the older it is a reminder of a cruel epoch' (Axell \& Kase, 2002: 3); more specifically, some Japanese consider the kamikaze pilots to have been 'irrational, heroic and stupid' (BBC, 2017). To non-Japanese, in contrast, it is probable that many maintain a perception of kamikaze pilots as 'men willing, almost gladly, to die in the name of their country and for the sake of their emperor... a soldier in a cockpit, ready to do his duty, piloting his plane into the deck of an American ship ... and in death, becom[ing] something noble' (Konstantopoulos, 2007: 6). Either way, however, the narrative surrounding the phenomenon remains highly contested within Japan (Jeans, 2005; Sheftall, 2008) and, in all likelihood, misunderstood beyond the country's borders. Nevertheless, the historical events leading up to the official commencement of kamikaze attacks in 1944 are generally acknowledged, as are the broader cultural influences on the apparent willingness of the young pilots to undertake the missions. 


\section{The kamikaze strategy}

The Pacific War commenced on 8 December 1941 when, following the attack on Pearl Harbour, Britain and the USA declared war on Japan. The events leading up to the attack are complex (Costello, 1982). However, it is generally considered to have been the inevitable outcome of Japan's foreign policy, specifically its 1931 invasion and occupation of Manchuria (north-east China), leading some to consider the Pacific War as part of the wider Asia Pacific War of 1931-45 (Ienaga, 2008; Takenaka, 2015). Japan invaded Manchuria primarily to exploit the region's natural resources but also to fulfil the broader intention of establishing a 'New Order in East Asia' (Axell \& Kase, 2002: 21). This resulted in growing opposition amongst Western nations to Japan's international activities, culminating in the USA imposing, amongst other things, an embargo on the export of iron and aviation fuel to Japan. As a country with few natural resources of its own, this was seen as a threat to not only its international ambitions but its very survival, although the commencement of hostilities against the USA in 1941 and subsequent occupation of a number of territories in the region was also ironically seen by Japan as an opportunity to liberate Asia from the control of the world's then western colonial powers.

Initially, the country enjoyed a number of military successes; however, by mid-1942, the tide began to turn. In particular, the Battle of Midway in June of that year, in which much of Japan's naval air power was lost, was a turning point in the Pacific War and her armed forces began to suffer a number of setbacks. By mid-1944 it had become recognized by Japan's military leaders that the continuing advances of numerically superior American forces could no longer be countered by conventional tactics and, hence, with the Japaneseoccupied Philippines facing imminent attack, and in the face of overwhelming odds, the first Special Attack (tokkō) missions were launched against American ships in the October of that year. Subsequently, the kamikaze campaign reached its peak near Okinawa during the following summer, finally ending with the cessation of hostilities in August 1945.

It should be noted that the decision to authorize the Special Attack missions, most famously the kamikaze airstrikes but also utilizing manned torpedoes, or kaiten, suicide boats (shinyo) and suicide divers, was not universally accepted by Japan's military leaders. Particularly, some questioned the rationale of sending men to certain death but with less certainty with regards to successful outcomes (Axell \& Kase, 2002); for example, only an estimated 10 percent of kamikaze pilots actually crashed into their targets (BBC, 2017) whilst kaiten missions are believed to have sunk only three American ships at the cost of 106 kaiten 
pilots, many of whom died on training missions or because of equipment failure (NHHC, 2019). Equally, there is evidence to suggest that, for a variety of reasons, many of those who flew on kamikaze missions were not in fact willing volunteers (Sheftall, 2005). Some deliberately ditched their aircraft in the ocean rather than crashing into ships whilst many of those who survived (the war having ended prior to their missions taking place) subsequently revealed their unwillingness to participate (Axell \& Kase, 2002; BBC, 2017). However, not only did the process of 'volunteering' make it difficult to refuse but also the pilots '... knew there was no alternative. To refuse to fly was to show a lack of duty to their country and their parents.' (Chiran, 2017: 19), not least because of the tradition of honourable death, based upon the notion of bushido, that was deeply entrenched in the culture of the Japanese military.

\section{Bushido}

The concept of bushido, which translates literally as 'military knight ways' (Nitobé, 1908), can be traced back to the period of the Meiji Restoration from 1868. Its roots, however, lie in Tsunetomo Yamamoto's Hagakure (see Yamamoto, 2002). Written in the seventeenth century, this described the morals and ethics of the Samurai in general and, in particular, the belief that it was better to achieve 'one's aim in death... than a continued failure to do so in life' (Konstantopoulos, 2007: 11). The Hagakure was subsequently adopted by the early Meiji government as a means of unifying Japan; that is, as a means of transferring the loyalty held by the former Samurai warrior class to their feudal lords to a sense of loyalty to their emperor amongst the Japanese people more widely in the newly unified Japan.

In essence, then, bushido represents a moral code, a set of principles that the ancient Samurai were required to observe in all aspects of their lives, including justice, courage, benevolence, politeness, truthfulness, honour and loyalty (Nitobé, 1908). In his widely-cited essay, Nitobé (1908) explains that bushido is underpinned by the twin influences of Buddhism and Shintoism. On the one hand, Buddhism encourages a sense of trust in fate, acceptance of the inevitable and stoic composure in the face of adversity. On the other hand, Shintoism promotes loyalty above all to the Emperor, filial piety (respect for parents and elders) and, in particular, reverence for ancestral memory inasmuch as it is believed that the souls of the dead remain behind to watch over the living. Specifically, in Shintoism, those who die tragically or heroically can be worshipped as gods and therein can be found the second way in which young Japanese pilots were encouraged to die for their country, namely, through the development of the myth surrounding Yasukini. 


\section{The myth of Yasukuni: Noble enshrinement}

As noted earlier in this paper, Yasukuni Jinja in Tokyo is the focus of considerable controversy that relates broadly to the relationship between 'the post-war Japanese state and the war dead' (Breen, 2004: 76). On the one hand, there are those who claim that Yasukuni, where the nation's war dead are apotheosized, is a purely religious instution which should not be formally visited by the head of state. To do so is in contradiction of the separation of state and religon as enshrined in Japan's post-war constitution. This position is challeged, on the other hand, by those who argue that the state should rightfully honour its war dead; to not do so, it is argued, is to succumb to external political pressure. More specifically, however, it was the enshrinement of 14 Class-A war criminals at Yusukuni in 1978 and subsequent visits by a number of Japanese Prime Ministers that has fuelled this controversy (Inuzuka \& Fuchs, 2014).

A full consideration of the debate is beyond the scope of this paper (see, for example, Okuyama, 2009; Pye, 2003; Ryu, 2007; Shibuichi, 2005). Importantly, however, the contemporary controversy surrounding Yasukuni is the outcome of a process, commencing with the Shrine's establishment in 1869, through which not only dying for the Emperor in battle came to be seen in Japan as 'an act worthy of aspiration and a source of pride' (Takenaka, 2015: 2) but also the war dead became the 'protector god for Japan' (ibid., 27). This process is referred to by Takenaka (2015:26) as the development of the Myth of the War Experience in which death in battle came to be seen as both sacrifice and resurrection; moreover, fundamental to this process was the adaptation of traditional death rituals in Japan.

At risk of simplification (see Takenaka, 2015 for a detailed discussion), in such rituals the founding ancestor of a family's lineage (or ie) was considered the family god who protected the living and, thus, was annually commemorated. Other family members who subsequently died would be commemorated for a prescribed period until their spirit was considered to have merged with that of the family god. Over time, however, this ritual was appropriated so that the emperor came to seen as the founding father of the family which, by extension, was the nation. As a consequence, the responsibility for commemorating war dead transferred from the family to the nation (at Yasukuni) and their spirits collectively became the god of Yasukuni, protector of the nation. Significantly, by the time of the Asia Pacific War, the spirits of the war dead at Yasukuni were also referred to collectively as eirei which, according to Takenaka, 2015, 90-93) is an invented term meaning noble spirits. Through the enshrinement process, war dead were cleansed of any wrong-doing during their lifetime, 
hence the justification for the inclusion of Class-A war criminals at Yasukuni and, arguably, the continuing limited sense of responsibility in contemporary Japanese society for their country's war time aggression.

In short, along with following the code of bushido, kamikaze pilots were, in a sense, offered the opportunity to not only sacrifice themselves for the nation and bring honour to their families, but also to become noble spirits collectively protecting the nation. And it is this cultural context of bushido and promised deification that goes some way to explaining the dissonant nature of their commemoration (and consequential implications for encouraging mutual understanding amongst all visitors) that is now discussed.

\section{Kamikaze heritage interpretation in Japan}

In order to explore the manner in which it is presented and interpreted for touristic consumption, visits were undertaken by the author to two of the country's principal kamikaze heritage sites: Chiran Peace Museum and Yūshūkan War Museum. At each site, field notes and, where appropriate, photographs were taken. In addition, secondary data sources, such as visitor comment books, English language guide books and related extant research were drawn upon, whilst relevant online sources were also accessed. Collectively, these facilitated a critical interpretative analysis of the messages conveyed by each museum.

\section{Chiran Peace Museum}

Chiran Peace Museum is located near the site of a former air base at the southern end of the island of Kyushu from where, in the final months of the Pacific War in 1945, many kamikaze missions were launched against the American fleet at Okinawa. In fact, 'more kamikaze pilots took off from Chiran than anywhere else' (Chiran, 2017: 5). Little evidence of the airfield remains; however, the Chiran Resource Centre was initially constructed by the town in 1975 to preserve and display memorablia, such as letters, photographs and others materials, from the kamikaze operations. In the mid-1980s, the Centre was redeveloped with state funding and re-opened in 1987 as the Chiran Peace Museum. Commemorating 1,036 kamikaze pilots (their average age was 21.6 years), almost half of whom flew out of Chiran, the museum now attacts more than 500,000 domestic vistors annually, as well as around 10,000 international visitors.

The dominance of the domestic market is not, perhaps, surprising given the museum's location, it being relatively distant from the typical international tourist itinerary in Japan. However, it is clear that from both a practical perspective and from the message it conveys 
the musuem is also designed primarily for the domestic audience. Regarding the former, an audio-tour in English is available but, with the exception of a sign in the main entrance hall and a small number of (arguably, carefully selected) translated letters from pilots to their families, all information and interpretation is in Japanese. Consquently, and as lamented by many (see Tripadvisor, 2020), the experience of international visitors is limited to and prescribed by the narration on the audio-guide. Notably, this commences by informing visitors that the museum refers to the pilots as tokkō rather than kamikaze because they attacked only military and not civilian targets. In so doing, an attempt is arguably being made to not only to legitimize the kamikaze strategy but also, perhaps, to distinguish it from the more recent Islamic suicide bombings with which commentators on the kamikaze phenomenon sometimes draw comparisons (Axell, 2002).

With regards to the latter, on approaching the museum building, visitors first encounter a full-sized replica of a kamikaze plane. This was used in the 2007 Japanese war movie, For Those We Love, written by Shintaro Ishihara, the then right-wing governor of Tokyo (Danielsen, 2007), which celebated the heroism of the kamikaze pilots. As such, it reflected the nationalistic and revisionst narrative of other recent Japanese war movies although, according to Danielson (2007), unlike the popularity of other movies, it 'proked disquiet' amongst audiences, not least for parallels drawn with contemporay ideology-driven suicide bombers. Nearby are the statues of both a kamikaze pilot and of Tome Torihama who owned a restaurant in the town where pilots would go, sometimes with their families, prior to departing on their final mission. She became known as tokko no haha or the "mother of special attack pilots' (Inuzaka, 2016: 151) and also featured in For Those We Love. Her restaurant is now a small museum. These installations immediately establish the focus of the museum on the pilots themeselves and, on entering the main building, this is confirmed when visitors are first confronted with a large mural (the 'Chiran Requiem') of a pilot being carried from his burning plane by angels. This serves to both represent the deification of the kamikaze pilots at Yasukuni and their honourable death but also, more significantly, sets the overall tone of the museum's perspective on the kamikaze phenomenon.

In front of the mural, a sign (referred to above, in English) states that ' ... the Peace Hall was built here in commemoration of the pilots who died heroically in the skies and to impart the historical realities behind their lives, as well as pray for enduring peace'. Next to the mural, a continual video shows original footage of the kamikaze missions, emphasizing the challenges the pilots faced in reaching their targets. Many planes are seen crashing into 
the sea, but successful attacks are also shown. Also, in an adjacent room, physical items are on display, including the wreckage of a plane recovered from the seabed off the coast of Kagoshima. These, along with other artefacts on diplay elsewhere in the museum, such as clothing and other equipment used by the pilots, are tangible and uncontroversial exhibits. They include a replica of an A-frame barracks hut, located between the museum and a modern shrine dedicated to them, in which pilots would have been billetted prior to their missions.

Most of the museum, however, is given over to photographs of each of the 1,036 pilots commemorated. Accompanying each photograph is a description of the individual's background, age, education, family and military experience. In addition, original copies of their final letters to family and loved ones can be seen in display cases beneath the photographs although, as noted above, with the exception of a small number of such letters displayed together in a separate section of the museum, these are not accompanied by translations into English. However, a selection of translated letters is provided in the museum's official booklet on the kamikaze phenomenon, The Mind of the Kamikaze (Chiran, 2017), available for purchase. Reproduced under themes such as 'The Mothers', 'Love for Children' and 'Friendships', these letters collectively convey a message of duty, selfless willing sacrifice, of respect and love for parents and family and happiness for dying for Emperor and country. For example, one letter says simply: 'Dear Parents and everyone in my family, At last the long awaited chance has come. It will be my honor to descend into the ocean with my enemy' (Chiran, 2017: 26). Another says 'Dear Mother and Brother, Now I will go. I feel truly happy....I am recalling how every morning when I left to go to elementary school I would say "See you later". Well, now I am leaving and I shall not return. I am truly satisfied' (p. 32), whilst a father writes to his daughters: '...Your father can't be the horse you ride on through life, so the two of you take care of each other. Please know your father is a happy man. He is riding a vehicle that will chase away our enemies. Become as great as your father' (p. 63). As such, these selected translations emphasize the extent of the adoption of the Myth of the War Experience discussed above and directly contradict accounts of the unhappiness with which many pilots contemplated their fate.

The theme of willing sacrifice is further exemplified in stories highlighted during the audio tour. One, also related elsewhere (Axell \& Kase, 2002), tells of how a wife killed herself and her children so that her husband would not be held back from fulfilling his duty; another, based on a photograph of five young pilots aged between 17 and 19 who are smiling and playing with a puppy, suggests that they were happy even though they were allegedly 
departing on their mission the day after the photograph was taken. Nevertheless, it is also acknowledged that, in contrast, at night time many young pilots could be heard 'weeping bitterly... because they were afraid of death and felt a deep sorrow for their very short life' (Chiran, 2017: 19).

Overall, then, not only does the museum portray the young Japanese pilots as willing actors in the kamikaze campaign, but also the narrative surrounding them emphasizes their individuality, youth and humanity, their honour and sacrifice. In other words, there is, as Allen and Sakamoto (2013: 1050) put it, a 'quasi hero worship...evident throughout the exhibits'. Not only is this focus on willing sacrifice 'consistent with Japanese revisionist approaches to the memories of the Asia-Pacific War' (Inuzuka, 2016: 157) but it is also a clear manifestation of dissonance as considered earlier in this paper. That is, the narrative presented at the museum can itself be challenged - and indeed, has been through the stories of those pilots and others who survived the war (Sheftall, 2005) and who have, therefore, been disinherited by the museum's interpretation - yet, of equal if not greater significance, other stories are also not told. No attempt is made, for example, to locate the kamikaze phenomenon within the context of the war or Japan's role in it; as one review on Tripadvisor (2020) notes, 'the museum merely glorified the sacrifices made by these kamikaze pilots, and totally side-stepped the issues of Japanese aggression and war responsibilities. In my opinion, this made the pilots' deaths totally worthless'. No reference is made to the dissent of some commanders and pilots opposed to the kamikaze strategy or to its quite evident futility. Similarly, no reference is made to the prevailing culture of honourable death within the Japanese military at that time, nor the lure of promised deification; and nor is it acknowledged that, in essence, those pilots were state-trained suicide bombers (Allen \& Sakamoto, 2013). Moreover, also absent is any reference to their targets or victims, to the equally futile deaths of the crews of American ships that suffered direct hits.

In short, the museum does not offer the knowledge or stories to enable its visitors, whether domestic or international, to begin to understand how and why, in the context of the last year of the Pacific War, the kamikaze phenomenon occurred and, in so doing, confront a difficult past. Rather, they are presented with a very specific, highly politicized and emotionally-laden story that, for some visitors, might elicit feelings of respect and sympathy for the pilots but for others, bemusement and perhaps even anger. In turn, this raises the question of whether the Chiran Peace Museum, as a site of difficult heritage, might promote peace and reconciliation amongst its visitors, whether it is in fact 'peace museum'. On the one hand, many comments made by visitors, reproduced in a volume available for visitors to 
read in a seating area in the museum, suggest that it does. Typically, reference is made to the futility and waste of war and to the need for peace, although such arguably inevitable generic sentiments are largely expressed through the lens of the sacrifice of the young kamikaze pilots; that is, it is not the (untold) stories or heritages of the Pacific War that encourage visitors to write 'never again', but the senseless loss of thousands of young lives. Moreover, some visitors are of the opinion that the pilots' sacrifice laid the foundations of contemporary peace, a subliminal message that, perhaps, the museum intends to convey.

On the other hand, other comments reveal a more critical perspective; one, for example, states: 'I am from Singapore... my country men also suffered...we lived through 3 half [sic] years of Japanese occupation' whilst another visitor (from Norway) simply observes: 'What a strange thing to call this place a peace museum!' (Chiran Visitors Book: 10-11). The latter comment reflects the conclusions of others who critique Chiran's interpretation of the kamikaze phenomenon, there being broad consensus that a museum that not only honours the pilots as heroes but implies that their actions led to peace (whereas in fact they prolonged conflict) cannot be thought of as a peace museum. As Inuzuka (2016: 126) observes, peace 'is not integrated rationally into the displays' messages and pacifism is promoted in a rather ambiguous way'. Thus, whilst it may feed a contemporary national identity amongst some Japanese visitors and, as a public institution, reflects the national ambition for promoting peace through its name, the museum's quite evident dissonance, or its disinheritance of many potential tourists from both Japan and overseas, suggests that rather than stimulating understanding and reconciliation, it in fact denies (particularly domestic) visitors the opportunity to confront collectively and openly a difficult, controversial past.

\section{Yūshūkan War Museum}

Located within the grounds of (and managed by) Yasukuni Jinja, Yūshūkan is a highly controversial museum - indeed, to some, it is more problematic than Yasukuni (Fallows, 2014) yet, to date, it has attracted far more limited academic attention (for example, Lambert, 2004; Yamane, 2009). It originally opened 1882 to house artefacts from the Meij era Imperial Japanese Army, but the collection was expanded following the first Sino-Japanese War (1894-5). The building was demolished after an earthquake in 1923; following reconstruction, it opened again in 1932 and was subsequently expanded to include an interactive area that proved to be popular amongst visitors. According to Yoshida (2007), and arguably reflecting public support for the country's militarism, 1.9 million people visited the museum complex in 1940. Following the Pacific War the museum was closed down and only 
opened again to the public in 1986 with a limited display, attracting relatively few visitors. However, after renovation and expansion, it reopened again in 2002 and 226,000 people visited the museum between July 2002 and May 2003 (Yoshida, 2007). Current visitor numbers and the balance between domestic and international visitors are not known although a significant number of international tourists were observed both in Yasukini and Yūshūkan during the author's visit.

As a war museum, Yūshūkan is not dedicated specifically to the kamikaze although not only is there a memorial statue of a kamikaze pilot loctated near its entrance but also, as discussed shortly, the kamikaze feature prominently in one section of the museum, referred to in the English language leaflet as the 'Noble Spirits Sentiment Zone'. Rather, the museum presents an extensive collection of military artefacts dating back to the Meiji era but with a particular emphasis on twentieth centrury conflicts, specifically the Asia Pacific War from 1937 onwards. Notably, five exhibition rooms and the so-called Great Exhibition Hall focus on the Pacific War, the latter including large exhibits such as a dive-bomber plane, a gliderbomber and a kaiten human torpedo. Interestingly, a model of a suicide diver is also on display in one of the smaller exhibition halls.

These physical exhibits are, as at Chrian, uncontroversial. Since 2002, however, the focus of the museum has also been on education; as Takenaka (2015: 173) observes, the objective of the musem is "educating the public on Japanese military history during the modern period and memorializing and honouring the spirits enshined'. Consequently, much of the museum is given over to displays, many summarized in English, that provide a narrative of Japan's military activities. And it is this narrative, conveying a highly revisionist history that reflects the ownership and management of Yūshūkan by Yasukini Jinja that is so controversial. Inuzuka and Fuchs (2014: 31), for example, argue that the museum 'promotes a position of militarism disguised as self-defense' that is emphasized in a film with English sub-titles that is shown continuously. It was, according to the narrative, the US that triggered the Pacific War whilst the aggressors were European nations who had colonized those countries on whose resources Japan depended. More bluntly, Fallowes (2014) writes:

The museum is shocking in its mendacity...It is entirely different to create a memorial to pay somber respect to those who died in a war... than it is to create a memorial that recasts an entire war in a glorified light, including over the widely recognized atrocities committed in that war. 
For example, on entering Yūshūkan, the visitor is immediately confonted with a locomotive used on the infamous death railway beween Thailand and Burma yet reference is made neither to how and why that railway was built, nor to the significant loss of life involved in its contruction. Similarly, the widely acknowledged Nanking Massacre is referred to as an 'incident' with no mention of the atrocities committed by the Japanese.

It is within this revisionist historical context promoting an imperialist ideology that the kamikaze are commemorated at Yūshūkan. Within the 'Noble Spirits Sentiments Zone' stands a statue of a kamikaze pilot, whilst cabinets display artefacts related the kamikaze campaign. The walls of the rooms are covered with photographs of the pilots and other war dead, the noble spirits enshrined at Yasukuni. However, as at Chiran Peace Museum, no attempt is made to explain how and why the young men were encouraged to volunteer or to acknowledge the waste of young lives. Rather, by association with the message conveyed by the museum as a whole, the kamikaze are presented and commemorated as heroic participants in a conflict in which Japan fought gloriously to defend herself against Western aggression. In other words, not only is the kamilkze heritage at Yūshūkan saturated with dissonance; it is also located within an inaccurate, militarist narrative that is more likely to elicit anger and disbelief than understanding and a desire for reconcilation amongst international visitors.

\section{Conclusion}

The kamikaze strategy arguably remains not only one of the most controversial Japanese military campaigns of the Pacific war but also one of the more misunderstood; the perception of young men seemingly willing to sacrifice their lives on behalf of their family, country and Emperor contradicts a more nuanced and complex reality. Moreover, from an international visitor perspective, the kamikaze phenomenon perhaps epitomizes the approach of the Japanese military to the Pacific War, to fight and die nobly to the end, whatever the cost. Thus, it would be logical to suggest that, given Japan's stated objective of seeking, through international tourism, to enhance mutual understanding and to fulfil its responsibility to international peace (MLIT, 2012), the country's kamikaze heritage offers a potentially powerful means of contributing to understanding and encouraging more harmonious international relations.

From the evidence presented in this paper, however, this opportunity has been avoided; in other words, the presentation of kamikaze heritage at the two sites considered in this paper competes with Japan's official proactive stance on promoting international peace 
and understanding. This reflects, in part, the fact that the myth of the military experience propagated by Yasukuni Jinja (and which enjoys some support in contemporary Japan) directly shapes the narrative of Japanese military history presented at Yūshūkan War Museum in particular. However, it also should also be noted that the presentation of Pacific War heritage more generally cannot be separated from contemporary Japanese politics which, on the one hand, have tended to support an apologist approach towards the country's Asian neighbours but, on the other hand, remain imbued with a sense of victimhood (Tsutsui, 2009). Moreover, according to Nakano (2016: 165), more recent years have witnessed the emergence of a new political elite 'often opposed to expressions of war guilt and contrition' and driving a new tide of nationalism, illiberalism and historical revisionism. Hence, the manner in which the kamikaze are commemorated as revealed in this paper has undoubtedly been shaped by a complex amalgam of contextual influences (Farmaki, 2017) and continues to be so. This, in turn, supports the more general argument that not only may what Ashworth and Hartmann (2005) consider to be inevitable dissonance at difficult heritage sites be enhanced by dominant political and cultural factors but also that, consequently, the achievement of understanding and reconciliation through tourism to such sites may be both complex and challenging.

This may not always be case. Nevertheless, to return to the specific purpose of this paper, it is evident that the nature of the comemmoration and interpretation of the kamikaze pilots at both Chiran and Yūshūkan, as far as it is accessible to international visitors in terms of translated information, raises more questions than it answers. Certainly, a visit to Chiran Peace Museum in particular will leave international visitors with the sense that the kamikaze pilots were brave and honourable young men who died for their country. Yet, they will be left with questions about the prevailing political and cultural system that left the pilots with no choice, and why contempoary Japan appears uanble to acknowledge and accept resonsibility for its wartime aggression. Moreover, given the overtly nationalistic and militarist narrative that is consumed by contemporary generations of Japanese domestic visitors at both sites, the potential for the strengthening of international relations in the future may also be questioned. 


\section{References}

Allen, M. and Sakamoto, R. (2013) War and peace: War memories and museums in Japan. History Compass, 11(12), 1047-1058.

Ashworth, G. and Hartmann, R. (2005) Horror and Human Tragedy Revisited: The Management of Sites of Atrocities for Tourism. New York: Cognizant Books.

Axell, A. (2002) The kamikaze mindset. History Today, 52(9), 3-4.

Axell, A. and Kase, H. (2002) Kamikaze: Japan's Suicide Gods. Harlow: Pearson Education.

Bar-Siman-Tov, Y. (2004) Introduction: Why reconciliation? In Y. Bar-Siman-Tov (Ed.), From Conflict Resolution to Reconciliation. Oxford: Oxford University Press, pp. 3-9

Batten, B. (2009) The Myall Creek Memorial: History, identity and reconciliation. In W. Logan and K. Reeves (Eds), Places of Pain and Shame: Dealing with 'Difficult Heritage'. Abingdon: Routledge, pp. 82-96.

BBC (2017) How Japan's youth see the kamikaze pilots of WW2. BBC News. Available at: https://www.bbc.co.uk/news/world-asia-39351262 (Accessed 17January 2020)

Blanchard, L. and Higgins-Desboilles, F. (2013) Peace through Tourism: Promoting Human Security through International Citizenship. Abingdon: Routledge.

Breen, J. (2004) The dead and the living in the land of peace: A sociology of the Yasukuni shrine. Mortality, 9(1), 76-93.

Buckley-Zistel, S and Schaefer, S. (2014) Memorials in Times of Transition. Cambridge: Intersentia Ltd.

Cano, L. and Mysyk, A. (2004) Cultural tourism, the state and the Day of the Dead. Annals of Tourism Research, 31(4), 879-898.

Chiran (2017) The Mind of the Kamikaze. Minamikyushu-shi: Chiran Peace Museum.

Costello, J. (1982) The Pacific War 1941-1945. New York: Harper Collins.

Crowe-Delaney, L. (2019) Japanese tourism in the late 20th and early 21st centuries. In T. O’Rourke and M. Koščak (Eds), Ethical and Responsible Tourism: Managing Sustainability on Local Tourism Destinations. Abingdon: Earthscan/Routledge, pp. 163-182.

D'Amore, L. (1988) Tourism: A vital force for peace. Tourism Management, 9(2), 151-154.

Danielsen, S. (2007) Japanese war movies aim to rewrite history. The Guardian, 23 May. Available at: https://www.theguardian.com/film/filmblog/2007/may/23/spanclassfloatrightbrsmalla eg (Accessed 7 April 2020) 
Fallows, J. (2014) Stop Talking About Yasukuni; the Real Problem Is Yūshūkan. The Atlantic, 2 January. Available at: https://www.theatlantic.com/international/archive/2014/01/stop-talking-aboutyasukuni-the-real-problem-is-y-sh-kan/282757/ (Accessed 20 January 2020).

Farmaki, A. (2017) The tourism and peace nexus. Tourism Management, 59, 528-540.

Friedrich, M. Stone, P. and Rukesha, P. (2018) Dark tourism, difficult heritage and memorialisation: A case of the Rwandan Genocide. In P. Stone et al. (Eds), The Palgrave Handbook of Dark Tourism Studies. London: Palgrave Macmillan, pp. 261289.

Funck, C. and Cooper, M. (2015) Japanese Tourism: Spaces, Places and Structures. New York / Oxford: Berghahn Books.

Gurler, E. and Ozer, B. (2013) The effects of public memorials on social memory and urban identity. Procedia: Social and Behavioral Sciences, 82, 858-863.

Hall, C.M., Timothy, D. and Duval, D. (2004) Security and tourism: Towards a new understanding. Journal of Travel \& Tourism Marketing, 15(2-3), 1-18.

Harrison, D. and Sharpley, R. (Eds), (2017) Mass Tourism in a Small World. Wallingford: CABI.

Ienaga, S. (2008) Pacific War, 1931-1945: A Critical Perspective on Japan's Role in World War II. New York: Presidio Press

Inuzuka, A. (2016) Memories of the Tokko: An analysis of the Chiran Peace Museum for kamikaze pilots. Howard Journal of Communications, 27(2), 145-166.

Inuzuka, A. and Fuchs, T. (2014) Memories of Japanese militarism: The Yasukuni Shrine as a commemorative site. Journal of International Communication, 20(1), 21-41.

Jeans, R. (2005) Victims or victimizers? Museums, textbooks, and the war debate in contemporary Japan. The Journal of Military History, 69(1), 149-195.

JNTO (2019a) Japan Tourism Statistics: Trends in Visitor Arrivals to Japan. Japan National Tourism Organisation. Available at: https://statistics.jnto.go.jp/en/graph/\#graph-inbound--travelers--transition (Accessed 24 December 2019).

JNTO (2019b) 2018 Visitor Arrivals and Japanese Overseas Travelers. Japan National Tourism Organisation. Available at: https://www.jnto.go.jp/jpn/statistics/data_info_listing/pdf/190116_monthly.pdf (Accessed 24 December 2019).

Kelly, I. and Nkabahona, A. (2010) Tourism and reconciliation. In O. Moufakkir, O. and I. Kelly (Eds), Tourism, Progress and Peace. Wallingford: CABI, pp. 228-241. 
Konstantopoulos, G. (2007) The Kamikaze Pilots and Their Image in World War II. Bachelor Thesis, Mount Holyoke College, South Hadley, MA. Available at: https://ida.mtholyoke.edu/xmlui/bitstream/handle/10166/731/228.pdf?sequence $=1$ (Accessed 17 January 2020).

Lambert, R. (2004) The maintenance of imperial Shinto in postwar Japan as seen at Yasukuni Shrine and its Yushukan Museum. Asia-Pacific Perspectives, 4(1), 9-18.

Light, D. (2017) Progress in dark tourism and thanatourism research: An uneasy relationship with heritage tourism. Tourism Management, 61, 275-301.

Litvin, S. (1998) Tourism: The world's peace industry? Journal of Travel Research, 37(1), 63-66.

Logan, W. and Reeves, K. (Eds) (2008) Places of Pain and Shame: Dealing with 'Difficult Heritage'. Abingdon: Routledge.

Lollis, E. (2014) Peace as a destination: Peace tourism around the world. In C. Wohlmuther and W. Wintersteiner (Eds), International Handbook on Tourism and Peace. Klagenfurt: Drava, pp. 294-309.

Milano, C., Cheer, J. and Novelli, M. (Eds) (2019) Overtourism: Excesses, Discontents and Measures in Travel and Tourism. Wallingford: CABI.

MLIT (2012) Tourism20 Nation Basic Plan. Ministry of Land, Infrastructure and Transport. Available at: https://www.mlit.go.jp/common/000234920.pdf (Accessed 22 December 2019).

MLIT (2016) Meeting of the Council for a Tourism Vision to Support the Future of Japan. Ministry of Land, Infrastructure and Transport. Available at: https://www.mlit.go.jp/common/001172615.pdf (Accessed 22 December 2019). Moufakkir, O. and Kelly, I. (2010) Tourism, Progress and Peace. Wallingford: CABI. Nakano, K. (2016) Political dynamics of contemporary Japanese nationalism. In J. Kingston (Ed.) Asian Nationalisms Reconsidered. Abingdon: Routledge, pp. 160-171.

Nelson, J. (2003) Social memory as ritual practice: commemorating spirits of the military dead at Yasukuni Shinto shrine. The Journal of Asian Studies, 62(2), 443-467.

NHHC (2019) The First Kaiten Suicide Torpedo Attack, 20 November 1944. Naval History and Heritage Command. Available at: https://www.history.navy.mil/aboutus/leadership/director/directors-corner/h-grams/h-gram-039/h-039-4.html (Accessed 21 January 2020). 
Nitobé, I. (1908) Bushido: The Soul of Japan. Ebook available at: https://www.gutenberg.org/files/12096/12096-h/12096-h.htm (Accessed 2 December 2018)

Okuyama, M. (2009) The Yasukuni shrine problem in the East Asian context: Religion and politics in modern Japan. Politics and Religion Journal, 3(2), 235-251.

Oros, A. (2015) International and domestic challenges to Japan's postwar security identity:

'Norm constructivism' and Japan's new 'proactive pacifism'. The Pacific Review, 28(1), 139-160.

Orr, J. (2001) The Victim as Hero: Ideologies of Peace and National Identity in Postwar Japan. Honolulu: University of Hawai'i Press.

Palmer, C. (1999) Tourism and the symbols of identity. Tourism Management, 20(3), 313321.

Pechlaner, H., Innerhofer, E. and Erschbamer, G. (Eds) (2020) Overtourism: Tourism Management and Solutions. Abingdon: Routledge.

Pratt, S. and Liu, A. (2016) Does tourism really lead to peace? A global view. International Journal of Tourism Research, 18(1), 82-90.

Pye, M. (2003) Religion and conflict in Japan with special reference to Shinto and Yasukuni Shrine. Diogenes, 50(3), 45-59.

Richter, L. (1983) Tourism, politics and political science: A case of not so benign neglect. Annals of Tourism Research, 10(3), 313-335.

Rifai, T. (2013) Foreword. In C. Wohlmuther and W. Wintersteiner (Eds), International Handbook on Tourism and Peace. Klagenfurt: Drava, p. 11.

Ryu, Y. (2007) The Yasukuni controversy: Divergent perspectives from the Japanese political elite. Asian Survey, 47(5), 705-726.

Sakamoto, R. (2015) Mobilizing effect for collective war memory. Cultural Studies, 29(2), 158-184.

Schäfer, S. (20160 From Geisha girls to the Atomic Bomb Dome: Dark tourism and the formation of Hiroshima memory. Tourist Studies, 16(4), 351-366

Sharpley, R. (2009) Dark tourism and political ideology: Towards a governance model. In R. Sharpley and P. Stone (Eds), The Darker Side of Travel: The Theory and Practice of Dark Tourism. Bristol: Channel View Publications, pp. 145-163.

Sharpley, R. and Friedrich, M. (2016) Genocide tourism in Rwanda: Contesting the concept of the 'dark tourist'. In G. Hooper and J. Lennon (Eds), Dark Tourism: Practice and Interpretation. Abingdon: Routledge, pp. 134-146 
Sheftall, M. (2005) Blossoms in the Wind: Human Legacies of the Kamikaze. New York: NAL Caliber.

Sheftall, M. (2008) Japanese war veterans and kamikaze memorialization: A case study of defeat remembrance as revitalization movement. In J. Macleod (Ed.) Defeat and Memory: Cultural Histories of Military Defeat in the Modern Era. Houndmills: Palgrave Macmillan, pp. 154-174.

Shibuichi, D. (2005) The Yasukuni Shrine dispute and the politics of identity in Japan: Why all the fuss? Asian Survey, 45(2), 197-215.

Siegenthaler, P. (2002) Hiroshima and Nagasaki in Japanese guidebooks. Annals of Tourism Research, 29(4), 1111-1137.

Smith, L. (2006) Uses of Heritage. Abingdon: Routledge.

Takenaka, A. (2015) Yasukuni Shrine: History, Memory and Japan's Unending Postwar. Honolulu: University of Hawai'i Press.

Tripadvisor (2020) Chiran Peace Museum. Available at: https://www.tripadvisor.co.uk/Attraction_Review-g1022938-d1545999-Reviewsor20-Chiran_Peace_Museum-Minamikyushu_Kagoshima_Prefecture_Kyushu.html (Accessed 22 January 2020)

Tunbridge, J. and Ashworth, G. (1996) Dissonant Heritage: The Management of the Past as a Resource in Conflict. Chichester: John Wiley \& Sons.

Tsutsui, K. (2009) The trajectory of perpetrators' trauma: Mnemonic politics around the Asiapacific war in Japan. Social Forces, 87(3), 1389-1422.

Wight, A. C. (2016) Lithuanian genocide heritage as discursive formation. Annals of Tourism Research, 59, 60-78.

Williams, P. (2007) Memorial Museums: The Global Rush to Commemorate Atrocities. Oxford: Berg.

Wohlmuther, C. and Wintersteiner, W. (2014) Tourism and peace: An emerging field of action and research. In C. Wohlmuther and W. Wintersteiner (Eds), International Handbook on Tourism and Peace. Klagenfurt: Drava, pp. 17-28.

WTO (1980) Manila Declaration on World Tourism. Madrid: World Tourism Organization. Yamamoto, T. (2002) Bushido: The Way of the Samurai (Based on the Hagakure: Trans. M. Tanaka, Ed. J. Stone). Garden City Park, NY: Square One Publishers.

Yamane, K. (2009) Moving beyond the war memorial museum. Peace Forum, 24(34), 75-84. Yasuaki, O. (2002) Japanese war guilt and postwar responsibilities of Japan. Berkeley Journal of International Law, 20, 600-620. 
Yoshida, K., Bui, H and Lee, T. (2016) Does tourism illuminate the darkness of Hiroshima and Nagasaki? Journal of Destination Marketing \& Management, 5, 333-340.

Yoshida, T. (2004) Whom should we remember? Journal of Museum Education, 29, 2-3.

Yoshida, T (2007) Revisiting the past: Complicating the future. The Yushukan War Museum in Modern Japanese History. History Faculty Publications, Paper 2. Western Michigan University. Available at: http://scholarworks.wmich.edu/history_pubs/2 (Accessed 23 January 2020) 